\title{
PENERAPAN TEKNOLOGI GAME BERHITUNG UNTUK MENINGKATKAN KEMAMPUAN MATEMATIKA PADA SISWA TINGKAT SEKOLAH DASAR
}

\author{
Muchamad Arif $^{1}$, Medika Risnasari ${ }^{2}$ \\ ${ }^{1}$ Program Studi PendidikanInformatika \\ UniversitasTrunojoyo Madura \\ Madura, Indonesia \\ muchamadarif83@gmail.com
}

\begin{abstract}
ABSTRAK
Salah satu pelajaran yang abstrak dan dianggap sulit oleh sebagian besar adalah matematika. Jadi diperlukan alternatif pembelajaran yang efektif yang dapat membuat siswa lebh mudah memahami dan lebih cinta dalam matematika. Salah satu cara mengajar matematika lebih kreatif dan menyenangkan adalah melalui permainan.

Disini, penulis mencoba unfruk memperkenalkan Mr.Moo. Ini adalah permainan berhitung dengan menggunakan sapi sebagai karakter hewan Madura. Mr.Moo menyajikan permainan matematika yang dilengkapi dengan pertanyaan-pertanyaan kreatif dari beberapa tingkat dari yang paling mudah sampai yang paling susah. Diharapkan permainan ini dapat meningkatkan kreativitas siswa dalam pengoperasian aritmatika di sekolah

Berdasarkan hasil validasi yang telah dilakukan pada siswa dan guru menunjukan bahwa permainan Mr.Moo memperoleh nilai 3.12 dari segi deainnya, itu berarti Mr.Moo adalah permainan yang baik dan cocok untuk siswa sekolah dasar. Dan dari isinya atau materinya, Mr.Moo mendapatkan nilai 3,45 yang berarti bahwa Mr.Moo adalah cara yang efektif untuk meningkatkan ketrampilan siswa dalam menghitung disekolah dasar.
\end{abstract}

Kata kunci: Matematika, permainan Mr.Moo, pembelajaran efektif

\section{ABSTRACT}

One of the abstract lesson and considered difficult for most students is math. So it is needed an alternative and effective learning which makes student is easier to understand and lover in mathematics. One of ways to teach mathematics more creative and fun is through games.

Here the writers try to introduce Mr.Moo. It is a counting game by using cow as the character of Madura animal. It present mathematics game which is completed by creative question and some levels from easier till the hottest. Hoppefully it can increase the students' creativity in operating arithmetic in elementary school.

According to validation testing that has been done both to students and teachers show that Mr.Moo game gets 3.12 point for its design, it means that Mr.Moo game is good for elementary school. From contens or materials, Mr Moo gets 3.45 point and its really an effective way to improve students skill in counting in the elementary school.

Keywords: mathematics, Mr Moo game, effective learning 


\section{PENDAHULUAN}

Ilmu Matematika merupakan ilmu dasar yang telah diperkenalkan kepada peserta didik sejak dini bahkan diajarkan oleh orang tua dalam lingkungan keluarganya. Mata pelajaran Matematika perlu diberikan kepada semua peserta didik mulai dari sekolah dasar untuk membekali peserta didik dengan kemampuan berpikir logis, analitis, sistematis, kritis, dan kreatif, serta kemampuan bekerjasama. Kompetensi tersebut diperlukan agar peserta didik dapat memiliki kemampuan memperoleh, mengelola, dan memanfaatkan informasi untuk bertahan hidup pada keadaan yang selalu berubah, tidak pasti, dan kompetitif.

Ilmu matematika merupakan ilmu universal yang mendasari perkembangan teknologi modern, mempunyai peran penting dalam berbagai disiplin dan memajukan daya pikir manusia. Perkembangan pesat di bidang teknologi informasi dan komunikasi dewasa ini dilandasi oleh perkembangan matematika di bidang teori bilangan, aljabar, analisis, logika, teori peluang, matematika diskrit dan lainnya yang bergantung pada displin ilmu teknologi informasi.

Teknologi informasi dan matematika mempunyai hubungan yang sangat erat. Perkembangan teknologi informasi tidak lepas dari peran ilmu matematika. Misalnya, pada kurikulum matematika pada tingkat sekolah dasar adalah konsep bilangan. Sedangkan teknologi informasi sering menggunakan perangkat computer. Ketika seseorang akan menggunakan maupun mengembangkan computer pastinya membutuhkan kemampuan matematika karena sebuah computer mampu mengelolah data informasi.

Pada umumnya, mata pelajaran matematika menjadi mata pelajaran yang ditakuti atau tidak diminati oleh peserta didik. Ketakutan ini dapat disebabkan karena sulitnya peserta didik memahami pelajaran matematika.
Pembelajaran matematika akan lebih bermakna dan menarik bagi peserta didik jika pengajar dapat menyajikan dalam bentuk masalah-masalah kontekstual dan realistik, yaitu masalah-masalah yang sudah dikenal, dekat dengan kehidupan sehari-hari peserta didik. Oleh karena itu, dalam pembelajaran matematika diperlukan sebuah metode pembelajaran yang membuat matematika menjadi ilmu yang disenangi dan mudah dipahami. Salah satu cara untuk meningkatkan kualitas pembelajaran matematika adalah dengan pengembangan media pembelajaran yang digunakan juga konsep penyajian seperti dalam bentuk permainan/game. Menurut Syaiful Bahri (1995: 136) menjelaskan didalam kegiatan belajar mengajar ketidakjelasan bahan yang disampaikan dapat dibantu dengan menghadirkan media sebagai perantara".

Dalam perkembangan teknologi informasi memang telah banyak beredar media pembelajaran interaktif baik dalam bentuk tutorial, permainan maupun cerita. Mata pelajaran matematika berhitung pun sudah banyak media pembelajaran dalam berbagai platform. Sehingga dilihat dari pentingnya penguasaan ilmu matematika di masa tingginya masyarakat memanfaatkan teknologi informasi, maka pada penelitian ini akan membuat sebuah media pembelajaran matematika pada tema berhitung untuk peserta didik kelas 1 tingkat Sekolah Dasar (SD). Media pembelajaran yang dibuat konsep permaian/game dalam penelitian ini mengacu pada tematik kurikulum 2013. Jika dilihat dari berbagai perilaku kebiasaan masyarakat saat ini adalah selalu menggunakan handphone, computer dan gadget lainnya. Perangkat canggih ini tidak hanya dimiliki oleh orang dewasa melainkan juga anak-anak. Perilaku kehidupan masyarakat ini maka pada penelitian ini media pembelajaran akan 
diaplikasikan pada perangkat yang menggunakan sistem operasi android. Sehingga anak-anak dapat memanfaatkan perangkat tersebut untuk belajar mengembangkan kompetensi mereka.

Dalam Kurikulum 2013 yang peneliti ambil dari Buku Tematik Kurikulum 2013, buku tema 3 untuk guru SD Kelas 1 yang diterbitkan oleh Kementerian Pendidikan dan Kebudayaan 2013 seperti pada gambar 1 dan 2 ini.

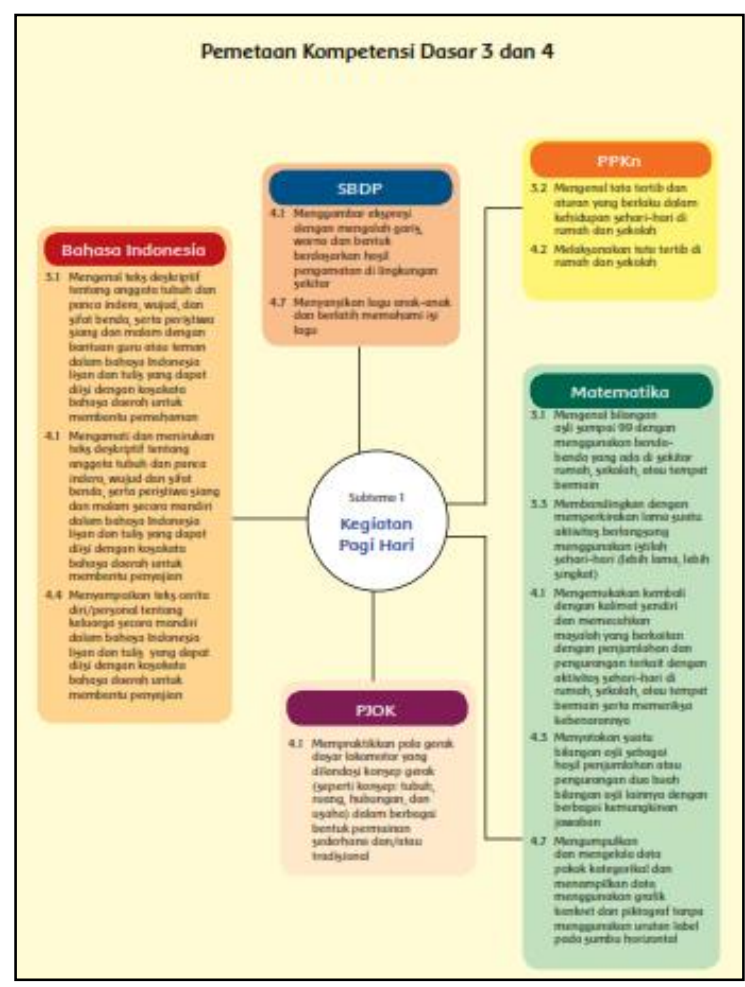

Gambar 2. Pemetaan Kompetensi Daar 3

dan 4 untuk SD kelas 1

Pembelajaran yang menggunakan teknologi informasi dan komunikasi atau menggunakan multimedia disebut dengan media pembelajaran berbasis multimedia interaktif. Penggunaan media pembelajaran ini dimaksudkan untuk membantu dosen dalam penyampaian materi dan juga membantu mahasiswa dalam memahami materi yang diajarkan. Selain itu muatan materi pelajaran dapat dimodifikasi menjadi lebih menarik dan mudah dipahami, tujuan materi yang sulit akan menjadi mudah, suasana belajar yang menegangkan menjadi menyenangkan.

Dengan menggunakan media pembelajaran berbasis multimedia dapat memadukan mediamedia dalam proses pembelajaran, maka proses pembelajaran

akan berkembang dengan baik, sehingga membantu dosen menciptakan pola penyajian yang interaktif. Multimedia interaktif merupakan kombinasi berbagai media dari komputer, video, audio, gambar dan teks. Berdasarkan definisi Hofstetter (2001) "multimedia interaktif adalah pemanfaatan komputer untuk menggabungkan teks, grafik, audio, gambar bergerak ( video dan animasi ) menjadi satu kesatuan dengan link dan tool yang tepat sehingga memungkinkan

pemakai multimedia dapat melakukan navigasi, berinteraksi, berkreasi, dan berkomunikasi”.

Keuntungan dan kelebihan menggunakan multimedia interaktif dalam pembelajaran diantaranya adalah sebagai berikut :

1. Sistem pembelajaran lebih inovatif dan interaktif.

2. Pengajar akan selalu dituntut untuk kreatif inovatif dalam mencari terobosan pembelajaran.

3. Mampu menggabungkan antara teks, gambar, audio, musik, animasi gambar atau video dalam satu kesatuan yang saling mendukung guna tercapainya tujuan pembelajaran.

4. Menambah motivasi pembelajar selama proses belajar mengajar hingga didapatkan tujuan pembelajaran yang diinginkan.

5. ampu menvisualisasikan materi yang selama ini sulit untuk diterangkan hanya sekedar dengan penjelasan atau alat peraga yang konvensional.

6. Melatih pembelajar lebih mandiri dalam mendapatkan ilmu pengetahuan. 


\section{Sistem Operasi Android}

Android adalah sistem operasi berbasis kernel Linux yang pada awalnya dikembangkan oleh Android, Inc, yang didukung Google finansial dan kemudian dibeli pada tahun 2005. Android ini diresmikan pada tahun 2007 seiring dengan berdirinya Open Handset Alliance-konsorsium hardware, software, dan perusahaan telekomunikasi yang ditujukan untuk memajukan standar perangkat selular.

Beberapa keunggulan dari system operasi android, antara lain:

1. User Friendly, sangat mudah mengoprasikan komputer hanya dengan belajar beberapa hari bahkan beberapa jam saja, dan ini juga melekat pada Android yang berjalan pada Smartphone.

2. Notifications, sangat mudah mendapatkan notifikasi dari smartphone android dengan mengatur beberapa akun Email, SMS , Voice Dial, Update dan lain sebagainya.

3. Tampilan

4. Open Source - Operating system ini memang dibuat open source oleh penciptanya, karena memang berbasis kernel Linux.

5. Aplikasi, terdapat aplikasi yang menarik dari yang gratis hingga berbayar, dan anda bisa mendownloadnya di Google Play.

\section{Unity}

Unity merupakan game engine buatan Unity Technologies yang dirilis tahun 2005 dan hanya dapat berjalan pada platform Mac OS. Saat ini unity sudah tersedia dalam platform windows dengan versi terbaru.

Beberapa keunggulan Unity adalah:

1. Game yang di develop dapat di deploy ke dalam beberapa platform sekaligus termasuk paltform mobile, web, desktop mauoun console

2. Penggunaan relatif mudah dan fitur relatif lengkap

3. Tersedia berbagai macam plugin

4. Banyak digunakan perusahaan game dari skala indie samapi perusahaan besar

5. Harga relatif terjangkau

Penelitian tentang media pembelajaran dengan berbagai tema, berbagai platform, berbagai software telah banyak dilakukan daintaranya

1. Penelitian pada tahun 2007 oleh Sunaryo Soenarto selaku dosen di Program studi D3 Teknik Elektro Fakultas Teknik Universitas Negeri Yogyakarta dengan judul jurnal Pembelajaran Berbasis Multimedia Sebagai Upaya Meningkatkan Kompetensi Hasil Belajar dan Persepsi Mahapeserta didik (Multimedia-Based Learning as an Effort to Improve Students Learning Achievement and Perception). Dalam penelitiannya Sunaryo Soenarto menyimpulkan bahwa: (a) Pencapaian hasil belajar mahapeserta didik yang mengikuti perkuliahan berbasis multimedia lebih baik dibandingkan dengan hasil belajar mahapeserta didik yang mengikuti perkuliahan berbantuan media overhead projector, (b) Mahapeserta didik memberikan persepsi baik terhadap pelaksanaan perkuliahan Elektronika Dasar berbantuan overhead projector sebesar 67,20\%, sedang mahapeserta didik memberikan persepsi baik terhadap pelaksanaan perkuliahan Elektronika Dasar berbasis multimedia sebesar 74,66 \%.

2. Penelitian oleh Arik Kurniawati dalam "Studi Analisis Tools Pembelajaran Berbasis Game Dalam Upaya Peningkatan Kompetensi Keahlian Pemrograman" Hasil penelitian yang 
telah dilakukan berkenaan dengan

3. Game Based Learning sebagai tambahan media dalam kuliah Algoritma Pemrograman maka pendekatan Game Based Learning ternyata dapat meningkatkan motivasi dan ketertarikan mahasiswa dalam belajar bahasa pemrograman. Selain itu, melalui media pembelajaran berbasis game khususnya untuk pemrograman, ternyata dapat membantu mahasiswa dalam memahami materimateri kuliah Algorima Pemrograman.

\section{METODE PENELITIAN}

Penelitian ini merupakan penelitian pengembangan yang mengembangkan media pembelajaran interaktif game berhitung untuk meningkatkan ketrampilan berhitung siswa kelas 1 sekolah dasar.

\section{Prosedure Penelitian}

\section{Tahap Pendefinisian}

Pada tahapan pendefinisian dilakukan dengan maksud untuk mengetahui apa yang dimaksud dengan media pembelajaran game berhitung yang menggunakan unity dan juga mencari hal - hal yang berkaitan dengan referensi/studi literature yang nantinya digunakan sebagai referensi dalam melakukan penelitian. Dalam penelitian ini akan dilakukan analisis permasalahan dan pengumpulan data penunjang penelitian.

Dalam analisis masalah ini, peneliti melakukan sejumlah analisi permasalahan dari pengamatan secara langsung maupun dengan studi literature sehingga menghasilkan ide untuk menentukan konsep desain, materi dan evaluasi dalam pengembangan media pembelajaran game berhitung. Setelah analisis masalah, peneliti melakukan sejumlah pengumpulan data untuk menunjang pembuatan media pembelajaran game berhitung

\section{Tahap Perancangan}

penggunaan media pembelajaran

Dalam tahap ini akan dilakukan perancangan dari desain media pembelajaran yang meliputi desain template, animasi, gambar dan audio yang akan digunakan dalam penelitian.

\section{Membuat Desain}

Dalam proses desain dimulai dengan melakukan tampilan slide awal dan slide masing-masing level

a. Tampilan awal

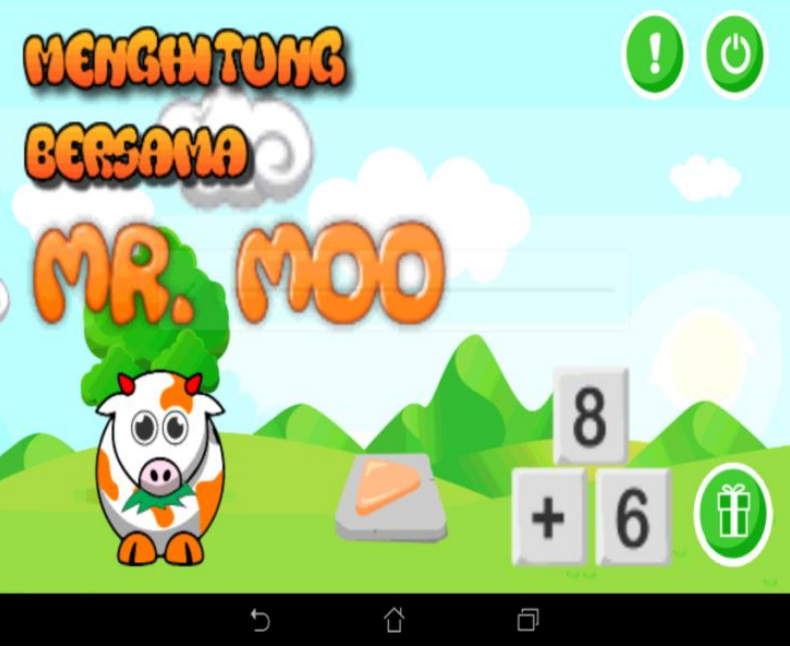

b. Slide tampilan level 1

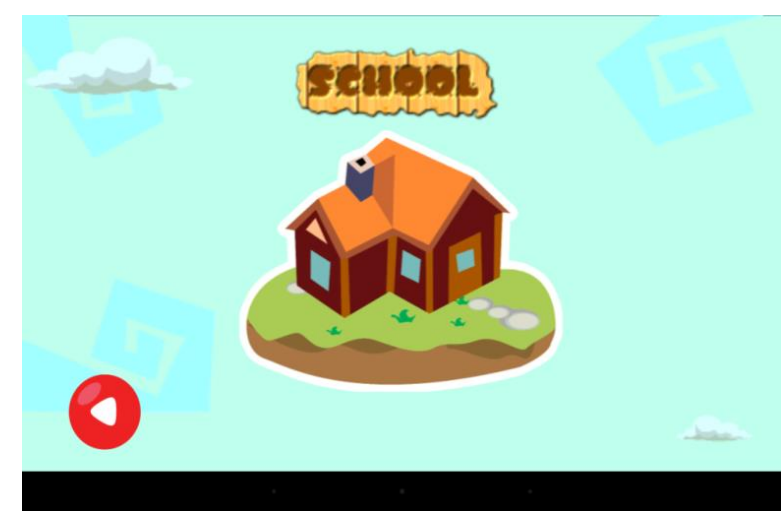

c. Slide tampilan petunjuk permainan

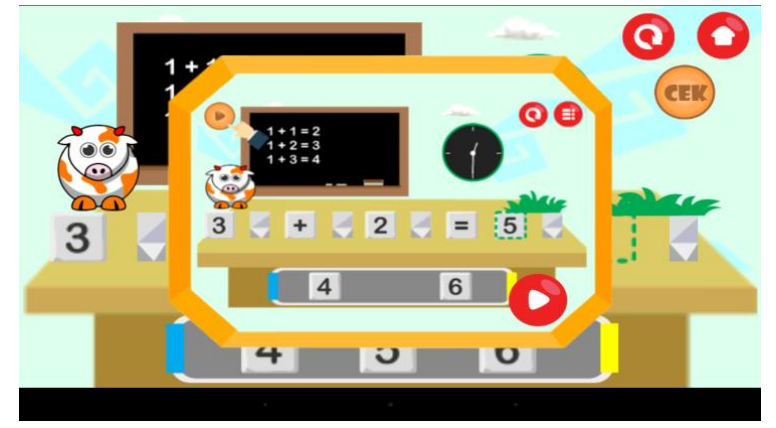


Tahap_Pengembangan

Proses pengembangan merupakan bagian utama dari penelitian ini, untuk bisa melakukan pengembangan dan mengetahui bagian mana saja yang bisa dilakukan pengembangan maka tahap ini dilakukan pengujian dan perbaikan hingga terselesainya penelitian.

\section{Tahap Penyebaran}

Dalam tahap ini penyebaran dilakukan sebagai bagian tingkatan dari sosialisasi hasil penelitian yang sifatnya tidak mengikat.

Secara umum metode penelitian yang akan dilakukan seperti pada gambar berikut ini:

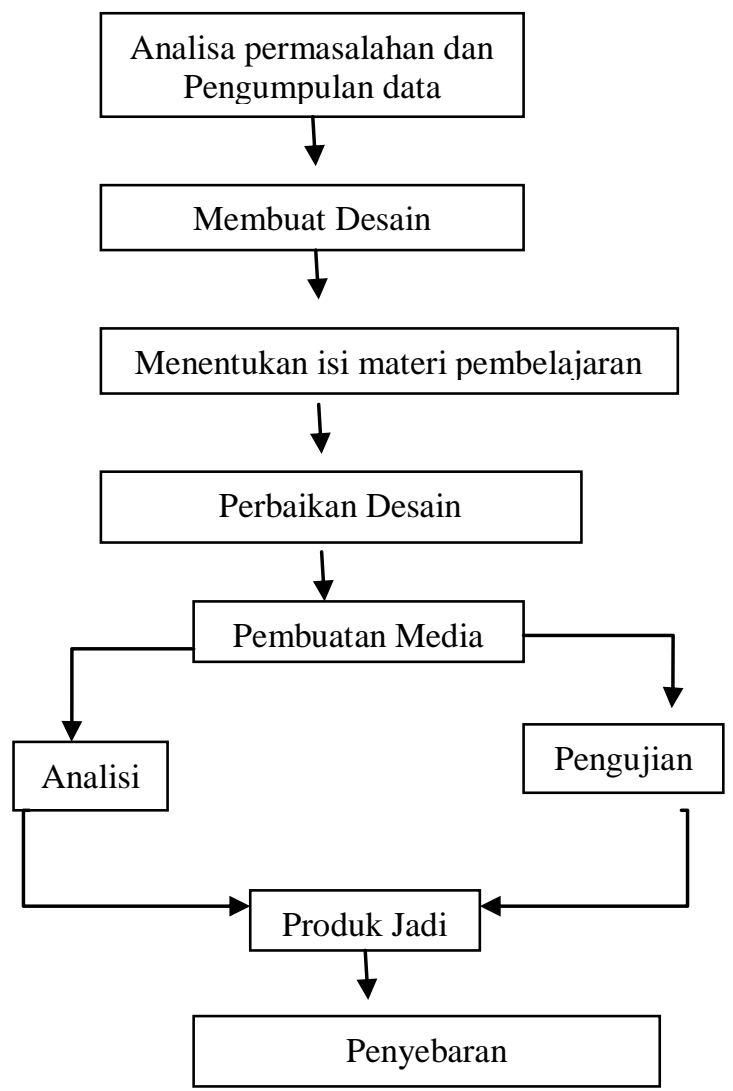

Gambar 3.1. Metode Penelitian

\section{Instrumen Pengumpulan Data}

Untuk memperoleh sejumlah data yang diharapkan, digunakan instrumen pengumpul data sebagai berikut:

\section{a. Angket}

Merupakan cara pengumpulan data dengan membuat pertanyaan-pertanyaan yang akan dijawab oleh sasaran uji coba guna mengetahui informasi dari responden tersebut. Instrumen yang diguanakan dalam penelitian yaitu berupa lembar penilaian yang berupa angket yang meliputi:

a. Lembar penilaian terhadap aspek desain game berhitung

b. Lembar penilaian terhadapaspek materi game berhitung

\section{b. Wawancara}

Digunakan untuk mengumpulkan data yang berhubungan dengan multimedia pembelajaran interaktif berbasis komputer. Teknik wawancara digunakan untuk melengkapi data yang diperoleh dari penggunaan angket. Data dari wawancara bersumber pada para peserta didik saat uji perorangan, uji kelompok kecil, dan uji kelompok besar (uji lapangan) mengenai produk multimedia pembelajaran interaktif ini.

\section{Teknik Analisis Data}

Teknik analisis data yang digunakan adalah dengan menggunakan teknik analisis kuantitatif dan pengukuran dilakukan dengan menggunakan skala likert.

Data kuantitatif dari tiap-tiap item instrumen dihitung dengan menggunakan teknik analisis nilai rata-rata, diadaptasi dari pendapat Arikunto. Arikunto (2006:242) menyatakan bahwa untuk mengetahui peringkat terakhir untuk butir yang bersangkutan, jumlah nilai tersebut harus dibagi dengan banyaknya responden yang menjawab angket tersebut. Berdasarkan hal tersebut, dapat dirumuskan perhitungan nilai rata-rata sebagai berikut:

$$
\mathrm{X}=\frac{\sum X}{n}
$$

Keterangan:

$$
\mathrm{X}=\text { nilai rata-rata }
$$

$\sum \mathrm{X}=$ jumlah total nilai jawaban dari responden

$\mathrm{n} \quad=$ jumlah responden 


\section{HASIL DAN PEMBAHASAN}

Hasil dari media pembelajaran game berhitung dengan menggunakan unity materi berhitung kelas 1 sekolah dasar terdiri dari beberapa tampilan menu, yaitu

1. Tampilan petunjuk permainan

Petunjuk permainan didesain sesederhana dan sejelas mungkin dengan menggunakan tools yang familier dalam memainkan sebuah game.

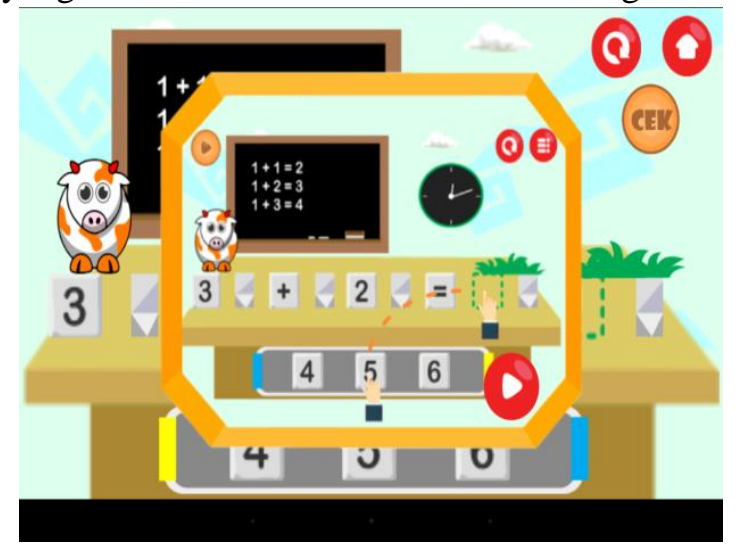

Gambar 4.1 Petunjuk permainan

\section{Tampilan materi tiap level}

Media pemebelajaran game berhitung ini terdiri dari 4 level. Level satu sampai tiga berisi soal-soal operasi penjumlahan dan pengurangan yang semakin lama semakin meningkat tingkat kesulitannya, sedangkan level 4 beraupa ketangkasan dalam bermain game

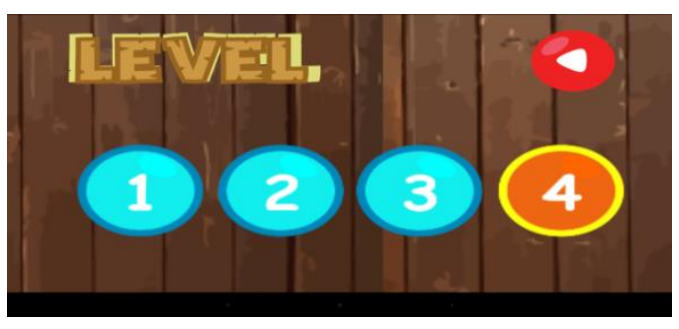

Gambar 4.2 Desain setiap level

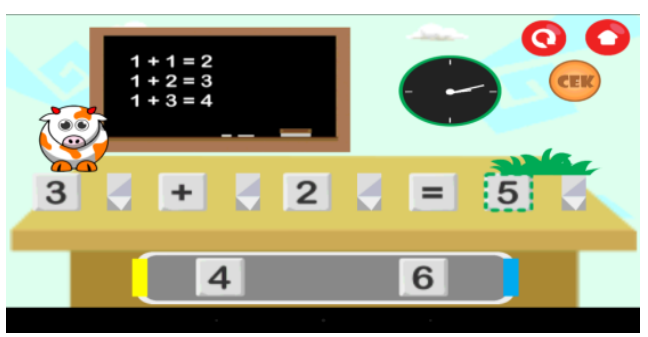

Gambar 4.3 Slide level 2
3. Tampilan kartu pemenang

Kartu pemenang akan muncul jika memenangkan setiap level yang ada. Kartupemenang berisi tentang obyekobyek pariwisata yang ada di pulau madura

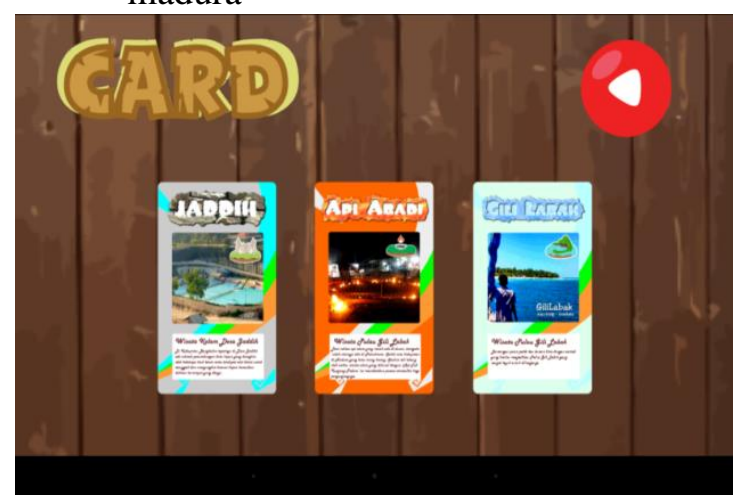

Gambar 4.4 Kartu Pemenang

\section{Hasil Validasi desain game berhitung}

Validasi Desain game berhitung dilakukan dengan tujuan untuk mengetahui respon pengguna terhadap desain game, petunjuk penggunaan, navigasi atau tomboltomboli yang tersedia, tampilan warna dan suara serta karakter Mr. Moo sehingga desain game berhitung benar-benar layak untuk digunakan

Tabel 4.1. Hasil skor Analisis validasi desain game berhitung

\begin{tabular}{|c|c|c|c|c|c|c|c|}
\hline \multirow{2}{*}{ No } & \multicolumn{4}{|c|}{ Responden/skor } & \multirow{2}{*}{$\begin{array}{l}\text { Skor } \\
\text { total }\end{array}$} & \multirow{2}{*}{$\begin{array}{l}\text { Rata } \\
\text {-rata } \\
\text { skor }\end{array}$} & \multirow{2}{*}{ Kriteria } \\
\hline & 1 & 2 & 3 & 4 & & & \\
\hline 1 & 2 & 3 & 3 & 4 & 12 & 3 & Baik \\
\hline 2 & 4 & 3 & 4 & 4 & 15 & 3.75 & Sangat baik \\
\hline 3 & 3 & 4 & 4 & 4 & 15 & 3.75 & Sangat baik \\
\hline 4 & 3 & 2 & 4 & 3 & 12 & 3 & Baik \\
\hline 5 & 3 & 3 & 3 & 3 & 12 & 3 & Baik \\
\hline 6 & 3 & 3 & 3 & 3 & 12 & 3 & Baik \\
\hline 7 & 4 & 4 & 3 & 4 & 15 & 3.75 & Sangat baik \\
\hline 8 & 4 & 3 & 3 & 3 & 13 & 3.25 & Baik \\
\hline 9 & 2 & 3 & 3 & 3 & 11 & 2.75 & Kurang baik \\
\hline 10 & 3 & 3 & 3 & 3 & 12 & 3 & Baik \\
\hline
\end{tabular}


Kriteria untuk penskoran adalah sebagai berikut :

Rata-rata 0,00 - 1,99= Tidak baik

Rata-rata 2,00 - 2,99 = Kurang baik

Rata-rata 3,00 - 3,49= Baik

Rata-rata 3,50 - 4,00 = Sangat Baik

Dari table 4.1 kita dapatkan informasi bahwa empat poin yang mendapatkan respon kategori sangat baik dari responden, lima respon kategori baik dari responden dan satu respon kurang baik dari responden. Sedangkan hasil validasi secara deskriptif desain game berhitung tampak pada table berikut:

Tabel 4.2. Hasil validasi terhadap desain game berhitung

\begin{tabular}{llc}
\hline No & \multicolumn{1}{c}{ Pernyataan } & Kriteria \\
\hline 1 & Bentuk desain & Baik \\
2 & Petunjuk game & Sangat Baik \\
3 & Penggunaan game & Sangat baik \\
4 & Tampilan warna & Baik \\
5 & Karakter Mr.Moo & Baik \\
6 & Tampilan navigai & Baik \\
7 & Tampilan soal & Sangat Baik \\
8 & Karakter suara & Baik \\
9 & Kartu kemenangan & Kurang baik \\
10 & Game berhitung & Baik \\
\hline
\end{tabular}

Secara keseluruhan hasil validasi desain game berhitug dengan menggunakan menggunakan teknik analisis nilai rata-rata, diadaptasi dari pendapat Arikunto. Arikunto (2006:242) menyatakan bahwa untuk mengetahui peringkat terakhir untuk butir yang bersangkutan, jumlah nilai tersebut harus dibagi dengan banyaknya responden yang menjawab angket tersebut. Berdasarkan hal tersebut, dapat dirumuskan perhitungan nilai rata-rata sebagai berikut:

$\mathrm{X}=\frac{\sum X}{n}$

Keterangan:

$\mathrm{X}=$ nilai rata-rata

$\sum \mathrm{X}=$ jumlah total nilai jawaban dari responden

$\mathrm{n} \quad=$ jumlah responden
Kriteria untuk penskoran adalah sebagai

berikut :

Rata-rata $0,00-1,99=$ Tidak valid

Rata-rata 2,00 - 2,99 = Kurang valid

Rata-rata 3,00 - 3,49= valid

Rata-rata 3,50 - 4,00 = Sangat valid

berdasarkan table 4.1 , maka didapatkan skor total sebesar 125 dari 10 item angket yang digunakan untuk mengetahui validditas desain game berhitung dengan menggunakan 4 orang sebagai responden diperoleh skor rata-rata sebesar 3,125 sehingga dapat disimpulakan desain game berhitung dikatakan valid, artinya desaingame berhitung layak untuk digunakan

\section{Hasil validasi materi game berhitung}

Validasi materi dilakukan dengan tujuan utama apakah soal-soal yang ada dalam game berhitung sesuai dengan kompetensi dasar yang ada di kelas 1 sekolah dasar. Selain itu digunakan untuk mengetahui efektifitas dalam meningkatkan ketrampilan berhitung dan penguasaan konsep matematika

Tabel 4.3. Hasil skor Analisis validasi materi game berhitung

\begin{tabular}{|c|c|c|c|c|c|c|c|}
\hline \multirow{2}{*}{$\begin{array}{l}\text { No } \\
\text { ang } \\
\text { ket }\end{array}$} & \multicolumn{4}{|c|}{$\begin{array}{l}\text { Responden } \\
\text { /skor }\end{array}$} & \multirow[t]{2}{*}{$\begin{array}{l}\text { Skor } \\
\text { total }\end{array}$} & \multirow[t]{2}{*}{$\begin{array}{l}\text { Rata-rata } \\
\text { skor }\end{array}$} & \multirow[t]{2}{*}{ Kriteria } \\
\hline & 1 & 2 & 3 & 4 & & & \\
\hline 1 & 3 & 3 & 4 & 4 & 14 & 3.5 & Sangat Baik \\
\hline 2 & 3 & 3 & 3 & 3 & 12 & 3 & Baik \\
\hline 3 & 3 & 3 & 4 & 3 & 13 & 3.25 & Baik \\
\hline 4 & 3 & 4 & 4 & 3 & 14 & 3.5 & Sangat Baik \\
\hline 5 & 3 & 3 & 3 & 4 & 13 & 3.25 & Baik \\
\hline 6 & 4 & 4 & 4 & 3 & 15 & 3.75 & Sangat Baik \\
\hline 7 & 4 & 3 & 3 & 4 & 14 & 3.5 & Sangat baik \\
\hline 8 & 3 & 3 & 3 & 3 & 12 & 3 & Baik \\
\hline 9 & 4 & 4 & 4 & 4 & 16 & 4 & Sangat Baik \\
\hline 10 & 4 & 4 & 4 & 3 & 15 & 3.75 & Sangat Baik \\
\hline
\end{tabular}

Kriteria untuk penskoran adalah sebagai berikut :

Rata-rata 0,00 - 1,99= Tidak baik

Rata-rata 2,00 - 2,99 = Kurang baik

Rata-rata 3,00 - 3,49 = Baik

Rata-rata 3,50 - 4,00 = Sangat Baik 
Dari table 4.3 kita dapatkan informasi bahwa terdapat enam poin yang mendapatkan respon kategori sangat baik dari responden dan empat poin mendapat respon kategori baik dari responden. Sedangkan hasil validasi secara dskriptif desain game game berhitung tampak pada table berikut:

Tabel 4.4 Hasil validasi Materi game berhitung

\begin{tabular}{llc}
\hline No & Pernyataan & Kriteria \\
\hline 1 & Respon siswa & Sangat Baik \\
2 & Soal level 1 & Baik \\
3 & Soal level 2 & Baik \\
4 & Soal level 3 & Sangat Baik \\
5 & Soal level 4 & Baik \\
6 & Tingkat kesulitan & Sangat Baik \\
7 & Tampilan soal & Sangat Baik \\
8 & Pemahaman konsep & Baik \\
9 & Kreativitas bernalar & Sangat baik \\
10 & Ketrampilan & Sangat Baik \\
& berhitung & \\
\hline
\end{tabular}

berdasarkan table 4.4, maka didapatkan skor total sebesar 138 dari 10 item angket yang digunakan untuk mengetahui validditas desain game berhitung dengan menggunakan 4 orang sebagai responden diperoleh skor rata-rata sebesar 3,45 sehingga dapat disimpulakan desain game berhitung dikatakan efektif dalam meningkatkan ketrampilan siswa dalam berhitung

Kriteria untuk penskoran adalah sebagai berikut :

Rata-rata 0,00 - 1,99= Tidak efektif

Rata-rata 2,00 - 2,99= Kurang efektif

Rata-rata 3,00 - 3,49= efektif

Rata-rata 3,50 - 4,00 = Sangat efektif

Hasil analisis wawancara

Berdasarkan hasil wawancara dari responden diperoleh saran dan masukan untuk menyempurnakan lagi desain maupun konten game berhitung sehingga lebih aplikatif,interaktif dan lebih menarik sehingga ketrampilan berhitung dan pemahaman konsep siswa dalam matematika lebih baik lagi
Dari sisi desain saran dan masukan yang kami terima sebagai berikut:

1. Desain sudah menarik tetapi alangkah lebih baik lagi tiap level memiliki desain yang berbeda sehingga lebih variatif lagi

2. Karakter Mr. Moo diperbesar lagi agar kelihatan lucu dan menarik

3. Pada level 4 soal yang dimuculkan terlalu kecil tulisannya dan karakter musuh terlalu besar bentuknya

4. Untuk petunjuk game sebaiknya gambarnya berjalan otomatis

5. Back ground game diusahakan berlatarbelakang pulau Madura atau tempat wisata di Madura

Sedangkan dari sisi konten saran dan masukan yang kami terima sebagai berikut:

1. Soal level 3 dirasa terlalu sulit untuk siswa kelas 1 sekolah dasar dan game berhitung ini sebenarnya cocok untuk siswa SD secara keseluruhan

2. Soal-soal yang disajikan hendaknya lebih variatif dan diperbanyak sehingga apabila ada 2 atau lebih yang bermain game pada level yang sama tipe soalnya bisa berbeda

3. Untuk level 4 soal yang disajikan lebih ditingkatkan lagi

4. Soal-soal yang disajikan bisa ditingkatkan dalam bentuk puluhan sehingga tidak hanya angka satuan aja yang muncul

5. Level permainan ditambah sampai 10 level sehinggga ketrampilan siswa dalam berhitung benar-benar teruji

6. Operasi dalam permainan ditambah lagi yaitu perkalian dan pembagian

\section{DAFTAR PUSTAKA}

Arikunto, suharsimi. 2002. Prosedur penelitian Suatu Pendekatan Praktek. Jakarta: PT Rineka Cipta

Anwar,Oos M. 2003. Model Inovasi Elearning dalam Meningkatkan Mutu Pendidikan. Jurnal Teknodik: Edisi No. 12/VII/Oktober/2003 
Richard A. Schwier dan Earl R. Misanchuk. 1993. Interactive Multimedia Instruction. New jersey: Eduacational Technology Publications

Bob Philips. 1997. The developers Handbooks to Interactive Mutimedia: A practice Guide for Educational Applications. London: Kogan page Limited

Roedavan, Rickman. 2014. Unity: Tutorial Game Engine: Informatika Bandung

Zikky, Mohammad. " Modul Pelatihan Unity 3D". Departemen Multimedia Kreatif, Politeknik Elektronika Negeri Surabaya 